\title{
The Skills of Using History Textbooks in Secondary School
}

\author{
Abdul Razaq Ahmad ${ }^{1}$, Mohd Mahzan Awang ${ }^{1}$, Ahmad Ali Seman ${ }^{1} \&$ Ramle bin Abdullah ${ }^{2}$ \\ ${ }^{1}$ Faculty of Education, Universiti Kebangsaan Malaysia, Selangor, Malaysia \\ ${ }^{2}$ University of Sultan Zainal Abidin, Malaysia, Malaysia \\ Correspondence: Abdul Razaq Ahmad, Faculty of Education, Universiti Kebangsaan Malaysia, 43600 UKM \\ Bangi, Selangor, Malaysia. E-mail: razaq@ukm.my
}

Received: August 1, 2013 Accepted: August 16, 2013 Online Published: August 30, 2013

doi:10.5539/ass.v9n12p229 URL: http://dx.doi.org/10.5539/ass.v9n12p229

\begin{abstract}
This study aims to explore the quality of Malaysian history textbooks from the perspectives of teachers and students as well as to identify the skills of using history textbooks among teachers and students. The survey respondents comprised of one hundred teachers and one hundred students that were randomly selected from national secondary schools in Malaysia. The survey used questionnaire as an instrument to collect data. Data analysis involves descriptive and inferential statistics. The results show that Malaysian history textbooks are not only used as a reference, but also as teaching aids. Although the majority of teachers and students are satisfied with the quality of textbooks, the following aspects have become an issue: quality of language, illustrations and repetition of topics. The skills of using textbooks among teachers and students are average. Overall, this study showed that teachers are not fully proficient in using the history textbooks especially in creativity and integrating the content of the textbooks with the information and communication technology (ICT). Results also showed that there was no significant difference between genders in using textbooks. This study recommends that the Ministry of Education of Malaysia should organise special training for enhancing the skills of using history textbooks for both teachers and students. This will guarantee that the history textbooks are used effectively.
\end{abstract}

Keywords: skills, history textbooks, creativity, quality

\section{Introduction}

History is related to the past. Throughout history, one can learn about the success of the nation. This allows the remembrance of past glories, instilling patriotism and subsequently honouring and preserving the independence and sovereignty of the country. This can be seen through the syllabus of the subject in 2000, which stated that the lesson is to promote and strengthen the spirit of national loyalty and identity as a Malaysian citizen. Teaching history can create a reminiscence of historical events as the frame of reference of national awareness and international understanding (Ministry of Education, 2001). Malaysian history textbooks are used as a tool to achieve that goal. Achievement of these goals is reflected in the content of history textbooks. For instance, history textbook for upper secondary school, in Malaysia, contains nine chapters in which the first three chapters are related to nationalism in the Southeast Asia and Malaysia. It is then followed by five chapters covering the struggles in relation to the formation of Malaysia and the development of this country, whilst the final chapter entails the global issues related to Malaysia.

History textbook is one of the important teaching and learning aids. It is often used as a resource in the teaching and learning history. Yet the book invites few debating issues. Among them is the dull presentation of the book (Abdul Razaq Ahmad \& Isjoni, 2009). At the same time the topics and contents are separated and it is difficult for students and teachers to relate these facts to the subject as a whole (Abdul Rahim Rashid, 2000).

In Malaysian context, the textbook is used as the main raw materials and sources of information about the subject in the implementation of the Integrated Curriculum for Primary Schools (ICSS) in school. Textbooks also reflect society's values and hopes as well as aspirations of a nation. In Malaysia, the history textbook includes national principles, loving community and Vision 2020 in order to achieve the developed country status according to the Malaysian framework. Textbook mirrors the government's capability. Historical development of Malaysian education has shown that changes in policy have always been followed by the formulation of new curriculum and new syllabus as well as the preparation of new textbooks. For example, the Old Curriculum of History subject has been replaced by the new Integrated Curriculum for secondary schools that is known as ICSS 
since 1989. This new history curriculum emphasises the importance of critical thinking, patriotism, nationalism and history thinking.

Textbooks play an important role in Malaysian education system. According to the circular distributed by the Ministry of Education of Malaysia (in 2001), teachers and students are required to use the textbook as the main source in teaching and learning history. This situation is supported by research that shows there is a positive correlation between the use of textbooks and academic achievement when the majority of the teachers recognize the importance of textbooks as teaching and learning resources (Marohaini Yusoff Abd Murad Salleh \& Shahrir Jamaluddin, 2005). However, there are some issues with regards to the use of textbooks where most of the teachers and students are not skilful and creative in using the textbooks. In addition, previous research showed that the textbook itself does not meet the needs of students' academic achievement at various levels. That research also suggests that there is no special training in the use of textbooks as subject matter in the school textbooks to become more important than exercises and illustrations (Marohaini Yusoff, Salleh \& Abdul Murad Shahrir Jamaluddin, 2005).

According to the Textbook Division, Ministry of Education of Malaysia (2001), there are certain characteristics concerning the quality textbooks. First, textbooks convey information about the knowledge, concepts, ideas, facts and principles to students. Second, they provide materials for students to master the skills. Third, they instil and embrace the values and attitudes which are ultimately adopted by the students. Fourth, textbooks present the content in a clear, systematic and logical way. Fifth, they contain an element of assessment such as activities and practices. Finally, they use relevant and interesting graphical material, serving to support the text. Marohaini Yusoff Abd Murad Salleh and Shahrir Jamaluddin (2005) have emphasized the importance of the quality textbooks for effective teaching and learning history. The aspects of quality textbooks that include the use of language, illustration, design, and questions are very important in influencing the teachers and students to use a textbook. Thus, evaluations of the quality aspect are closely related to the study of the use of textbooks.

In a related study, Ping (2006) found that students' perceptions of the content of textbooks showed that only few respondents agreed with the suitability of the content in history textbook, while $20 \%$ of the respondents did not understand and were not interested in the textbook contents. However, it is difficult to make a correlation between the qualities of textbooks with students' interest, because there are other factors that affect students' interests and attitudes towards their studies.

A study conducted by Kamarul Azmi (2010) on Excellent Teacher of Islamic Education (ETIE) through a case study of eight secondary schools throughout Malaysia showed that textbooks, computers and projector are among the teaching aids used frequently. Data from the study showed the importance of mastering teaching aids including textbooks in making teaching and learning more effective and successful. Farrant (1977) emphasizes the importance of using teaching aids effectively as it will help students to understand the lesson. He also recommended that textbooks should have the quality of presentation, content, size, colour and usability.

\section{Issues and Problems}

Malaysia is a country with a centralised education system. All government schools use a standardized curriculum and all students are required to attend at least three national examinations namely Primary School Assessment Test, Lower Secondary Assessment, and Malaysian Certificate of Education examination. History subject is a compulsory subject for all government schools and all students must pass the history subject. To ensure that students learn the history of Malaysia based on accurate and authentic sources, the Ministry of Education of Malaysia has standardized textbooks for all subjects including history. Although there are some improvements in the textbooks as an initiative to enhance the interest of students, reports and past studies show that students are not interested in learning the subject (Ministry of Education, 2003; Rohana Zubir, 1987). Past studies on the quality of Malaysian history textbooks have focused on the aspects of content, but not on the aspects of quality of illustrations and usability aspects of reference materials and teaching aids (Centre for Policy Initiatives, 2011). Although past studies highlight that teaching aids such as textbooks attract and motivate the students to give full attention to the class (Kamarul Azmi, 2011), very few studies, if any, have been carried out to explore the skills of using history textbooks among teachers and students. In fact, until now, there is no specific study undertaken to identify the skills of using history textbook. Thus, this study fills the gap.

\section{The Purpose of Study}

This study aims to identify the use of Malaysian history text books for the secondary schools from both teachers and the students' perspectives. Regarding the teachers, the study focuses on their perceptions of the skills of using history textbooks, suggestions to improve and modify the quality of history textbook, while concerning the students, the study involves their perceptions of the quality of textbooks and the teachers' skills of using 
textbooks. Moreover, the study also differentiates the above mentioned issues based on genders.

\section{Methodology}

This study used survey approach as it enables the collection of data for the purpose of description, comparison or explanation regarding knowledge, attitudes, practices and behaviour (Fink, 1995). Two sets of questionnaires were used to collect data. The first set of the questionnaires entails the skills of using the history text books from the teacher's perspectives and teachers' recommendations in terms of improvement in the quality of history textbooks. The second set of questionnaires consists of sections related to students' attitudes and interests in history textbooks, their perceptions of the quality of textbooks and teachers' skills of using textbooks from students' perspectives. The questionnaire was adapted from Abdul Rahim Rashid (1993). Then, a panel of experts was recruited to validate the questionnaires in terms of face validity and content validity. In addition, the result of the pilot study revealed that Cronbach Alpha was between 7.8 and 7.9, that is, all the items in the constructs are at acceptable level regarding reliability and internal consistency. The samples consisting 100 teachers and 100 students were selected randomly from ten secondary schools in the state of Pahang in Malaysia. The rationale for selecting the samples from the state of Pahang is that compared to the other states, the result of the students' examination in history subject is average. Accordingly, they could make an appropriate sample for the current study. Furthermore, as the selected teachers have taught the students from the same schools, thus they can also be a suitable sample for this study. The obtained data was analysed using descriptive and inferential statistics using SPSS 11.5.

\section{Teachers' Perceptions}

Overall results suggest that the teachers' skills in using textbooks is quite high (mean=3.67). However, there are some elements regarding creativity (item 2), innovation (item 4), attractive leaning (item 8) which are still average. The contents and facts in history textbooks also become alive through teachers' effort to associate them with daily life. However, the teachers' creativity can be enhanced when students reported that teachers rarely integrate historical content into the history textbooks with the latest technology of ICT (mean = 3.04). Data also showed that the students admit that teachers often use history textbooks (mean=4.13) and also guide students regularly (mean $=4.07$ ). It is proven that the teachers make history textbooks as reference materials and teaching aids without letting students examine the facts contained therein. In fact, the students stated that teachers succeed in making history textbooks as an interesting media.

Regarding the teacher's perspectives, they admit that they have quite high skills in using history textbooks (mean=3.68). Data shows that teachers often guide the students to understand history by using textbooks (mean=4.38), and often take the initiative to simplify the content of history textbooks. The teachers admitted that they rarely integrate ICT (mean $=3.25$ ) with history textbooks. This shows that creativity is an issue that requires in-depth study in future research. Isjoni and Abdul Razaq Ahmad (2009) recommend that teacher's creativity is the pillar for effective teaching history. Farrant (1977) states that a misrepresentation occurs in defining the function of teaching aids which stems from the practice and the decrease in frequency of use during the process of teaching and learning. However, this deficiency should be addressed through modification and creativity of a teacher.

Table 1. The skills of using history textbooks from the teacher's perspectives

\begin{tabular}{|c|c|c|c|c|}
\hline & Item $(n=100)$ & Mean & $\begin{array}{l}\text { Frequency } \\
\text { Deviation }\end{array}$ & Level \\
\hline 1 & $\begin{array}{l}\text { I use the textbook merely as a teaching aid without consulting other } \\
\text { books. }\end{array}$ & 2.38 & 0.74 & Low \\
\hline 2 & I always simplify their subject matter / text found in textbooks. & 4.38 & 0.52 & High \\
\hline 3 & I always associate the content of textbooks with the latest issues. & 4.13 & 0.64 & High \\
\hline 4 & $\begin{array}{l}\text { I always modify the subject matter contained in the textbook with the } \\
\text { aid of ICT. }\end{array}$ & 3.25 & 0.71 & Medium \\
\hline 5 & I always guide students to understand the text in the textbook. & 4.38 & 0.74 & High \\
\hline 6 & I use the textbooks as a Medium effectively. & 3.38 & 1.19 & Medium \\
\hline 7 & $\begin{array}{l}\text { I prefer to refer other reference material and not rely solely on history } \\
\text { textbooks. }\end{array}$ & 4.25 & 1.17 & High \\
\hline
\end{tabular}


8 I manage to make teaching and learning more interesting even if only $\quad \begin{array}{ll}3.25 & 1.04\end{array}$

Medium using history textbooks as reference material.

Average

$3.68 \quad 0.84$

Table 2. Teachers' skills of using textbooks from students' perspectives

\begin{tabular}{|c|c|c|c|c|}
\hline & Item $(n=100)$ & Mean & $\begin{array}{l}\text { Deviation } \\
\text { Frequency }\end{array}$ & Level \\
\hline 1 & My history teacher uses appropriate texts in his teaching. & 4.13 & 0.87 & High \\
\hline 2 & $\begin{array}{l}\text { My history teacher uses textbooks only as teaching aid } \\
\text { without other books. }\end{array}$ & 3.07 & 0.99 & Medium \\
\hline 3 & $\begin{array}{l}\text { My history teacher can relate contents in textbooks with latest } \\
\text { issues. }\end{array}$ & 3.98 & 1.03 & High \\
\hline 4 & $\begin{array}{l}\text { My history teacher always modifies the contents of textbooks } \\
\text { in relation to ICT }\end{array}$ & 3.04 & 0.88 & Medium \\
\hline 5 & $\begin{array}{l}\text { My History teacher always guides me to understand the text } \\
\text { in the textbooks. }\end{array}$ & 4.07 & 0.74 & High \\
\hline 6 & $\begin{array}{l}\text { During the learning of history my teacher always makes the } \\
\text { books as good teaching aids. }\end{array}$ & 3.89 & 0.92 & High \\
\hline 7 & $\begin{array}{l}\text { I prefer that my history teacher does not refer to textbooks } \\
\text { alone, but uses various sources. }\end{array}$ & 3.73 & 1.21 & High \\
\hline 8 & $\begin{array}{l}\text { I feel happy learning history with teacher who uses textbook } \\
\text { alone in the class. }\end{array}$ & 3.16 & 1.13 & Medium \\
\hline
\end{tabular}

The teachers claim that they can make teaching and learning interesting and effective by using history textbooks as reference materials. Nevertheless, it does not mean that history teachers rely on purely historical texts. Data shows that teachers do not merely rely on history textbooks (mean $=2.38$ ). Initiatives taken in diversifying learning resources help to make teaching and learning more relevant to the current situation and might promote students to become active.

Table 3. The skills of using textbooks among teachers based on gender

\begin{tabular}{lllllll}
\hline Dependent Variables & Gender & $\mathrm{n}$ & Mean & Mean Difference & $\mathrm{t}$ & Sig \\
\hline Students' Attitudes towards textbooks & Male & 47 & 3.6383 & .0086 & .097 & .055 \\
& Female & 53 & 3.6297 & & & \\
Total & & 100 & & & & \\
\hline
\end{tabular}

The analysis of t-test indicated that there was a significant difference between male and female teachers with regards to the skills of using textbook. This might be due to the standard of teachers' training courses organised by the Ministry of Education. A study by Nurliah Jair (2009) showed that there is no significant difference between genders in teaching history.

\section{Suggestion to Improve the Quality of Using History Textbooks}

Overall, the data show that the quality of history textbooks can be improved in line with students' expectation. Students want history textbooks to be modified in line with their interests. This is important as it serves as the main reference textbook thus modifications are necessary in order to attract students to the subject. Marohaini Yusoff Abd Murad Salleh \& Shahrir Jamaluddin, 2005) stressed the importance of the assessment of the quality or standard textbooks as one of the aspects of the studies. Quality textbooks are supposed to have a simple language, illustration, design, and relevant questions. They are very important in influencing teachers and 
students in using history textbooks effectively. This finding is consistent with Garinger (2001), who stated that textbooks should be modified including the contents of history textbooks and exercises. They should be presented in a clear and user-friendly way.

Table 4. Suggestions to improve the quality Malaysian history textbook

\begin{tabular}{|c|c|c|c|c|}
\hline & Item $(\mathrm{n}=100)$ & Mean & $\begin{array}{l}\text { Frequency } \\
\text { Deviation }\end{array}$ & Interpretation \\
\hline 1 & Wording should be modified to be understandable language. & 4.14 & 1.16 & High \\
\hline 2 & The content should be reduced. & 3.06 & 1.25 & Medium \\
\hline 3 & $\begin{array}{l}\text { Illustration for each event should be added to help me imagine } \\
\text { about certain events. }\end{array}$ & 4.44 & 0.91 & High \\
\hline 4 & Wordy texts should be changed into mind map. & 4.41 & 1.02 & High \\
\hline 5 & History textbooks should not contain repeated subject matter. & 3.74 & 0.94 & High \\
\hline \multirow[t]{2}{*}{6} & $\begin{array}{l}\text { Change the colour of illustrations to more attractive and } \\
\text { cheerful colour }\end{array}$ & 4.59 & 0.82 & High \\
\hline & Average & 4.061 & & \\
\hline
\end{tabular}

The findings of this study demonstrate that the quality of textbooks should contain interesting illustrations, colourful and simple sentences easy to understand, non-recurring, and can help the process of imagination. On the other hand, teachers insisted that the content in the history textbooks should be transformed into a more concise method, and also topics need to be reduced to enhance students' understanding when studying history. The teachers also agreed that history facts should be summarized and multiplied with beautiful photos, and be synthesized in the form of themes.

Table 5. Teachers' perceptions of modification of history textbooks

\begin{tabular}{|c|c|c|c|c|}
\hline & \multirow[t]{2}{*}{ Item $(n=100)$} & \multirow[t]{2}{*}{ Mean } & Frequency & \multirow[t]{2}{*}{ Interpretation } \\
\hline & & & Deviation & \\
\hline 33 & $\begin{array}{l}\text { The use of verse / language should be modified to a more } \\
\text { understandable language. }\end{array}$ & 4.63 & 1.06 & High \\
\hline 34 & The content available in textbooks should be reduced. & 3.50 & 1.19 & High \\
\hline 35 & $\begin{array}{l}\text { Illustrations should be added to help students to imagine about } \\
\text { certain historical events. }\end{array}$ & 4.75 & 0.46 & High \\
\hline 36 & Wordy texts should be changed to mind map. & 4.39 & 0.52 & High \\
\hline 37 & History textbooks should not contain repeated contents. & 4.50 & 0.76 & High \\
\hline 38 & $\begin{array}{l}\text { The colours in the text should be changed to more attractive } \\
\text { and cheerful colours. }\end{array}$ & 4.63 & 0.74 & High \\
\hline
\end{tabular}

The findings from this study highlight the need to improve history textbooks to a better quality that are able to attract students and assist the process of thinking for historical imagination. This is in line with the recommendations of previous researchers stressing that the use of textbooks is more important than the e-book if integrated with graphics and colours (Kamarul Azmi, 2010).

\section{Students' Perceptions}

\subsection{Quality History Textbook}

The overall findings showed that the students are satisfied with the quality of textbooks (average mean $=3.63$ ). This finding is consistent with the results of the previous study carried out by Ping (2006) who found that the subject content is appropriate to the needs of students. Similarly, the findings from the study conducted by Mohd 
Izham et.al, (2007) indicates that the teaching aids such as textbooks attract and motivate the students to give full attention to the teacher. This is because they are attractive and full of fun. Detailed analysis showed that five items recorded higher mean values, while the rest are average. The majority of students reported that the current history textbooks are interesting and providing many resources (mean=3.72). Most students also indicated that they used textbooks as a main reference for answering the questions. This means that the history textbooks are suitable and relevant to students' needs.

Table 6. Perceptions of students towards the quality of textbooks

\begin{tabular}{|c|c|c|c|}
\hline Item $(n=100)$ & Mean & $\begin{array}{l}\text { Frequency } \\
\text { Deviation }\end{array}$ & Level \\
\hline 1 I feel that history textbooks are interesting and contain many resources & 3.72 & 0.94 & High \\
\hline $\begin{array}{l}2 \text { I consider history textbooks as the primary source for answering the } \\
\text { questions }\end{array}$ & 3.83 & 0.78 & High \\
\hline 3. Textbooks that I read help me to earn good grades in exam. & 3.72 & 0.92 & High \\
\hline 4 Texts, sentences and languages in textbooks are easy to understand, & 3.33 & 1.02 & Medium \\
\hline $\begin{array}{l}5 \text { I feel bored when reading history textbooks because the contents are } \\
\text { too much and a lot of facts need to be memorised. }\end{array}$ & 3.44 & 1.23 & Medium \\
\hline $\begin{array}{l}6 \text { When reading textbooks, I can portray a historical event based on the } \\
\text { text and the illustrations shown. }\end{array}$ & 3.56 & 0.91 & Medium \\
\hline $\begin{array}{l}7 \text { The contents in the textbooks instil good values and positive attitudes } \\
\text { into students. }\end{array}$ & 3.89 & 0.98 & High \\
\hline $\begin{array}{l}8 \text { After reading the history textbooks, I found that the exercises provided } \\
\text { in the textbooks encourage me to think critically and creatively. }\end{array}$ & 3.56 & 0.82 & Medium \\
\hline $\begin{array}{l}9 \text { History textbook also contains information about website that can be } \\
\text { accessed for additional information }\end{array}$ & 4.11 & 0.90 & High \\
\hline 10 I feel good when studying textbooks & 3.27 & 1.10 & Medium \\
\hline Average & 3.63 & 0.97 & \\
\hline
\end{tabular}

Students are aware that more information can be obtained from the internet through the websites that were clearly stated in the textbooks. This shows that history textbooks have been integrated with the latest technology that can help students to get more information on the history of the country. Topics in the history textbooks are recognized by students as beneficial when they create positive attitudes through promoting good values. However, Malaysia's history textbooks could be further improved through increasing the quality of presentation of facts and exercises. For example, students reported that the structure and content of history textbooks contain wordy sentences which are boring for students.

\subsection{The Skills of Using History Textbooks}

The total mean value is at high level (mean $=3.63$ ) and this shows that students believe that history teachers have high skills in the use of textbooks in teaching and learning. However, the teachers are lacking in creativity to use the content of history textbooks in improving the students' critical and historical thinking. This indicates that the skills of using textbooks are necessary to make teaching and learning effective. Likewise, the findings supported by the past studies recommends that creativity in using textbooks is the main factor to determine the students' motivation and achievement in learning history (Awang, 2012).

\subsection{Quality and the Skills of Using Textbook Based on Gender}

The findings of the t-test showed that there was no significant difference concerning interest in learning history textbooks based on gender. This finding is contradicted with the past findings where there is significant difference between genders in learning other academic subjects (Sharifah Alwiah, 1983). This shows that the use of history textbooks is appropriate in terms of content and suitable for both genders. 
Table 7. Interest in learning history through textbooks based on gender from students perspectives

\begin{tabular}{lllllll}
\hline Dependent Variables & Gender & $\mathrm{N}$ & Mean & Mean Difference & $\mathrm{t}$ & Sig \\
\hline Student interest in history textbooks & Male & 47 & 3.5455 & 0.1498 & 1.569 & .123 \\
& Female & 53 & 3.3957 & & & \\
Total & & 100 & & & & \\
\hline
\end{tabular}

This finding is in line with Shahril's study indicating that students' attitudes towards teaching and learning tool are not dependent on gender, but on the effectiveness of teaching. Furthermore, a study conducted by Anuar Ahmad et al. (2009) showed that boys and girls have the same perspective of the teaching methods used by history teachers.

\section{Implications and Recommendations}

These findings can have impact on policy makers, including the Textbook Division and Ministry of Education to be more sensitive to the views of teachers and students regarding the quality of textbooks, because the history textbooks are mostly used by teachers and students. This study also has implications for writers of history textbooks in order to figure out a method of writing history text to be more attractive, simple, compact and non-repetitive. Creative illustrations in textbooks and the elements of integration with the environment and additional information via the website are the important issues in determining the quality of textbooks.

In addition, the design and questions in the textbooks are very important as a guide and a simple instrument to measure the level of student's achievement. This study also highlighted the importance of teachers to master the skill of using textbooks. As the creativity of history teachers are still at a moderate level, an initiative must be taken so that history teachers will use textbooks regularly as the primary instructional materials to make teaching and learning effective. Among the activities that can be applied is changing the way of using textbooks such as adapting the textbook content into a more attractive method, for example exploring the proposed web-site in the textbook for additional information. Activities must be carried out during the process of teaching and learning by involving students.

Improvement and enhancement of the content in the existing textbooks are vital since it is a reference book with high value of authenticity. In fact, it is the text of national exam. It makes Malaysian history textbooks as an official document that can be used to understand the history of the region. Therefore, a more detailed and in-depth study should be conducted especially in terms of quality and knowledge among teachers and students in schools. Further study should take into account the participation of respondents from all races, types of schools, locations of schools, levels of education, age groups and socio-economic towards the issue of quality of Malaysian history textbooks and mastery skills in school.

\section{Conclusion}

The current study found that the history textbooks are not only useful for reference and teaching aids, but also they can be used for attracting students' interest and stimulating students' historical thinking. The most important thing that has been found out from this study is associated with teachers' and students' creativities in using history textbooks. This makes the learning of history interesting and meaningful. This includes the use of ICT, the illustrations, portraits, photos, maps and diagrams. As a result, students' critical thinking in learning history will be improved. The effective use of history textbooks can improve the students' academic achievement and the goals of history education in Malaysia.

\section{References}

Ahmad et al. (2009). The level of History Teachers' Teaching Ability and Its Relationship to Student Achievement in Low Performing Schools. Journal of Education, Malaysia.

Ahmad, A. R., \& Isjoni. (2009). Strategies and History Learning Model. Cendikia Insani, Pekanbaru, Riau, Indonesia.

Ahmad, J. (1999). Guide to Teach Remedial Bahasa Melayu KBSR \& Secondary Schools. Shah Alam: Fajar Bakti Publishers.

Alsagof, S. A. (1986). Educational Pedagogy. Kuala Lumpur: Malaysia Heinemann.

Awang, M. M. (2012). An Exploration of Strategies Used by Malaysian School Teachers: Professionals' and Pupils' Perspectives. PhD Thesis, University of Dundee. 
Aziz, Z., \& Jair, N. (2009). Use of Mind Maps to Improve Performance Subjects History for secondary students. Journal of Education, Malaysia, 34(1), 3-15.

Centre for Policy Initiative. (2011). Committee and Council Meeting for Kem SMS and the Special Committee Reviewing Curriculum History and Secondary School History Textbooks. Retrieved February 18, 2013, from http://klscah.org.my/wp-content/uploads/2012/01/KemSMS-lampiran-3_191211-CPI.pdf

David, N. H. (2008). Student and Teacher Perceptions on the Use of History Textbooks Master Project. UKM.Bangi.

Farrant, J. S. (1977). Principle and Practice of Education. Kuala Lumpur: Dewan Bahasa Dan Pustaka.

Fink, A. (1995). The survey handbook (Vol. 1). Thousands Oaks, CA: Sage.

Garinger, D. (2001). Textbook evaluation. TEFL Web Journal. Retrieved February 18, 2013, from http://www.teflweb-j.org/v1nl/garinger.html

Isjoni, \& Ahmad, A. R. (2009). Teaching Transformation and History Teaching. Cendikia Insani, Pekanbaru, Riau, Indonesia.

Jasmi et al. (2011). The Practice of using teaching aids in Islamic Education for Excellent Teacher among Secondary School in Malaysia. Journal of Islamic and Arabic Education.

Jasmi, K. A. (2010). Excellent Teacher of Islamic School Education in Malaysia: A Case Study. PhD thesis. National University of Malaysia.

Marzuki, S. C. (2005). Effective Teachers Teaching Practice: Studies in several secondary schools in Malaysia. Teacher Education Research Seminar Makhtab Batu Lintang, BPG Jointly Organized by the Ministry of Education, Malaysia.

Ministry of Education Malaysia. (2001). Syllabus of Integrated Secondary School Curriculum. Putrajaya: Curriculum Development Centre, Ministry of Education.

Ministry of Education Malaysia. (2003a). The report on study of students'low interest in History Subject at 2009 Low Performance. Kuala Lumpur. Curriculum Development Centre.

Ministry of Education Malaysia. (2003b). Announcement of Results Certificate of Education in 2002. Kuala Lumpur. Curriculum Development Centre.

Ping, Y. W. (2006). Upper Secondary Student Perceptions In memorization of Historic Facts in Rural School in Sarikei. Seminar a Rural School Education Research, 2006. Teaching Institutions Rajang, Bintangor Sarawak.

Rashid, A. R. A. (2000). Model and Approch in KBSM History Teaching.Kuala Lumpur. Dewan Bahasa dan Pustaka.

Textbooks Divisions, School Department. (2008). Ministry of Education Website (On-line). Retrieved September 17, 2009, from http://www.gov.my

Woody, W. D., Daniel, D. B., \& Baker, C. A. (2010). E-books or textbooks: Student Prefer Textbooks. International Journal of Computers and Education, 55, 945-948. http://dx.doi.org/10.1016/j.compedu.2010.04.00571

Yusoff, M., Salleh, A. M., \& Jamaludin, S. (2005). Textbook Use among Teachers and Students in Secondary Schools: A Quantitative Survey. Paper presented at the Seminar on Educational Research, Batu Lintang Teachers Training College, September 15 to 16, 2005.

Zubir, R. (1987). Multimedia technology Application in Learning History: Implications and Problems. Journal of Educational Issues, 12, 89-98.

\section{Copyrights}

Copyright for this article is retained by the author(s), with first publication rights granted to the journal.

This is an open-access article distributed under the terms and conditions of the Creative Commons Attribution license (http://creativecommons.org/licenses/by/3.0/). 